\title{
Access to Urban Land and its Role in Enhancing Business Environment: Multi-track versus Mono-route Land-use Markets
}

\begin{abstract}
Access to urban land for business activities relates to access to working space, or using and/or controlling a unit of land based on open access, land ownership, land lease, business lease or premise rentals. Diversified and broad-based access to urban land with due regulatory control against speculation and holdouts enhances the dynamism and competitiveness of business activities, while on the contrary, mono-route land use markets such as municipal control of urban land provision suppresses the supply and transferability of land use rights thereby creating land use market imperfections. This article discusses the role of access to urban land and its transferability in enhancing the business environment, inter alia, as one of the major inputs in the production of goods and services. Rising urban population and correspondingly increasing business activities lead to urban intensification and urban frontier expansion to adjacent rural areas which should be addressed with prudence and caution in the context of accurate land information, efficient utilization of urban land, effective and transparent land governance and due attention to good practices in comparative legal regimes.
\end{abstract}

Elias N. Stebek *

\section{Key terms}

Access to urban land, business environment, urban land law, urban intensification, urban extensions, informal settlements, Ethiopia.

DOI http://dx.doi.org/10.4314/mlr.v9i1.1

\section{Introduction}

Every person occupies a space during each second of his/her lifetime. While most of the space we occupy at any given moment is public space (such as a street or an open space), there are units of land over which individuals, groups of persons, communities or juridical persons claim a spectrum of exclusive rights of use and control. Access to land does not thus mean dominion over

\footnotetext{
* Elias N. Stebek (LL.B, LL.M, PhD), Associate Professor, St. Mary’s University, School of Graduate Studies. An earlier version of this article was part of an unpublished research paper titled "Access to Urban Land for Private Sector Development in Ethiopia" (dated June 9, 2015) which was submitted to Private Sector Development Hub, Ethiopian Chamber of Commerce and Sectoral Associations.
} 
commoditized land as its 'master', per se, but access to be at a certain space, or use (and control) a certain plot of land (in common with others, as a member of a certain group or exclusively as an individual). It also involves the security, tenure and transferability of the access which is obtained.

In the context of business undertakings, the claim over well-defined and secure rights to use (and control) a certain space on land takes the forms of working space or business premises through open access, shared access, rental tenancy, leasehold, ownership and other forms. While most business activities merely use premises or floor spaces, others invest on the land. "Access to land with sufficient security to encourage investment for its efficient use and development is a vital component in development strategies for individuals, groups, cities and nations". This is more evident "in urban areas where demand, and therefore prices, of land for all uses are highest". 2

Land constitutes one of the factors of production, and access to land facilitates access to a key resource in value adding economic activities. On the contrary, inadequate access to land and restrictions thereof constitute entry and transferability barriers to enhanced economic activities thereby adversely affecting business environment and economic development. As Okoth-Ogendo duly observes, land "is an economic resource and an important factor in the formation of individual and collective identity, and in the day-to-day organization of social, cultural and religious life". 3 Moreover, land is "an enormous political resource that defines power relations between and among individuals, families and communities under established systems of governance". 4

The triadic functions of land as one of the foundations of our lives include (a) its role as the source and foundation for our natural resources which constitute inputs in the production of goods and services that relate to our basic needs; (b) its services as sink in the course of waste disposal and recycling; and (c) its function related to our aesthetic needs, amenities and reverence to nature. In its first function, land is the foundation of business undertakings in relation to the space, inputs and raw materials that are indispensible in all economic activities,

${ }^{1}$ Geoffrey Payne (1996), Urban Land Tenure and Property Rights in Developing Countries, A Review of the Literature, August 1996, Prepared for the Overseas Development Administration, p. 13.

2 Ibid.

${ }^{3}$ Okoth- Ogendo. Keynote Address at a Workshop on Land Tenure Security for Poverty Reduction in Eastern and Southern Africa. Organized by IFAD/ United Nations Office for Project Services/Ministry of Lands, Housing and Urban Development, Government of Uganda. Kampala, 27-29 June 2006 [in Improving access to land and tenure security, Policy, IFAD, December 2008, page 5].

${ }^{4}$ Ibid. 
particularly where the economy is factor-driven, a phase which countries undergo before their eventual transition to technology-driven and innovationdriven phases of production of goods and services. ${ }^{5}$ As noted by Kunte et al, land represents 30 to $50 \%$ of the national wealth in developing economies. ${ }^{6}$ This article deals with the significance of access to land, business premises and working space and the need for ease in their transferability to the most efficient user in the pursuit of enhancing conducive business environment. As the themes are general and comparative, this article does not relate most issues with the Ethiopian context. Other articles (such as the one which is concurrently published with this article) can address specific themes regarding access to urban land in Ethiopia.

The first section introduces the key issues that can be regarded as the constituent elements in access to land. Section 2 deals with the influence of access to urban land in improving ease in doing business and it also highlights land market imperfections. The third and fourth sections of the article deal with the challenges that are inherent in the course of enhanced urbanization through urban intensification and urban land expansion. The fifth section highlights the significance of land information and land governance in access to urban land. Sections 6 and 7 deal with tenure under public ownership of land, the misconceptions thereof, and a brief discussion on China's pursuits in urban land law reform with regard to tenure and transferability despite public ownership of land. The eighth section highlights some comparative experience regarding the scheme of incremental tenure titles for informal settlements.

\section{Key Issues in Access to Land}

Based on a 'systematic exploration of the land issues from the perspectives of private sector development,' Muir \& Shen suggest a taxonomy which captures 'the multilayered and interrelated obstacles facing private investors seeking access to land'. They indicate the following four key issues investors can face in relation to access to land:

- "Access: Is the land I need available? If so, from whom, at what price, and on what terms? How long will it take?

\footnotetext{
${ }^{5}$ See the elements in factor driven, technology driven and innovation driven economies, in World Economic Forum (2012), The World Competitiveness Report 2011-2012, Geneva.

${ }^{6}$ Arundhati Kunte, Kirk Hamilton, John Dixon, and Michael Clemens (1998), Estimating National Wealth: Methodology and Results, Departmental Working paper (World Bank, Washington, DC).

${ }^{7}$ Russell Muir and Xiaofang Shen (2005), "Land Markets: Improving Access to Land and Buildings by Investors", FIAS World Bank Group, October 2005.
} 
- Security. If I can get access to suitable land, what will be my rights over the land? Will my property rights be secure? Will I be able to use them as security for bank loans?

- Use. Once I have acquired land, how may I use and develop it? How long will it take to obtain all the permits for construction and related activitiesand how much will it cost?

- Consistency of treatment. Are my competitors being treated in the same way?"

Each key issue in this model has sub-themes and conditions that determine the impact of access to land on good business and investment environment. For example, the issue of Security involves "titling system, registration process, collateral rules, and transfer of property rights", while Use, embraces location permits, construction/building permits, environmental impact assessment and utility connections. We can use these key issues in conjunction with various indicators of business environment. For example, elements of business environment (used in World Bank Business Environment Snapshots) in accessing land include the strength of land lease rights, strength of business premise ownership rights, access to land information, time (number of days) to lease land from private land use right holders, and number of days to lease land from public entities. Ease in Doing Business indicators developed by the World Bank are also related with these key issues because five of the eleven indicators (as shown in Section 2) directly or indirectly relate to access to land.

Access to land in the context of conducive business environment further renders the issues of sustainability and other factors relevant. 'Future resilience' and sustainability of cities requires the anticipation and adaptation to prospective challenges of resource scarcity, population growth and climate change while at the same proactively working toward enabling cities to "support existing business and attract new ones". ${ }^{8}$ Various key drivers are noted to have impact on the decision of potential economic actors to "locate in a particular business environment", which include proximity to market, communication links (such as transportation and information technology), access to resources in terms of proximity and steady supply, availability and affordability of land and premises, skilled workforce, attractive living environment and government incentives. ${ }^{9}$ Thus access to urban land involves not only access to working space or the physical availability of land or business premises per se, but it further relates to various interrelated factors that deserve attention.

\footnotetext{
${ }^{8}$ Forum for the Future, Sustainable urban enterprise: creating the right business environment in cities (commissioned by Opportunity Peterborough), available at $<$ http://www.forumforthefuture.org/sites/default/files/project/downloads/opsustainableurba nenterprisereport.pdf $>$, Accessed: 30 December 2014.

${ }^{9}$ Ibid.
} 


\section{Access to Urban Land, its Influence in Doing Business, and Overview of Market Imperfections}

Various internal and external factors determine business environment. Laws such as the legal regime on access to land are among the external factors which determine the setting in which business operates.

Doing Business sheds light on how easy or difficult it is for a local entrepreneur to open and run a small to medium-size business when complying with relevant regulations. It measures and tracks changes in regulations affecting 11 areas in the life cycle of a business: starting a business, dealing with construction permits, getting electricity, registering property, getting credit, protecting minority investors, paying taxes, trading across borders, enforcing contracts, resolving insolvency and labor market regulation. ${ }^{10}$

These eleven indicators are compared annually among countries, and this enables comparison not only among countries but also among economies in a given region or sub-region. Six of the eleven indicators are directly of indirectly related with access to land: (a) Starting business envisages access to working space or business premise through owned premises, rentals or business lease. (b) Utilities including electricity are factors that render a working space or business premise usable. (c) Registration relates to various key elements of access to land such as adequate and reliable land registries, and the ease or difficulty in selling or mortgaging property. (d) Getting credit is, inter alia, enhanced or diminished by the scope of using landholdings as collateral for bank financing. (e) Trading across borders is related with access to land because this indicator refers to the convenience of a given location for trans-boarder trade which is one of the determinants in time and cost for sea transport (in relation to exports and imports). This indicator also includes the trade logistics regarding the time and cost of inland transport to the largest business city/cities of a county.

Access to land in the context of manufacturing, for example, usually envisages (a) acquiring land to construct business premises, or (b) buying business premises (or working space) as owner occupant, (c) premises rented for business, or (d) business lease. These options involve certain levels of certainty in duration. Manufactures, for example, have vested interest in the scope and security of lease and ownership rights. This evokes two core concerns related

${ }^{10}$ World Bank (2014), Doing Business 2015, Going Beyond Efficiency: Economy Profile 2015, Ethiopia (2014, The International Bank for Reconstruction and Development / The World Bank), p. 4. 
with access to land, i.e. availability of land in an efficient market, and secondly affordability of the price.

In a market economy, the forum for access to urban land is the land market. As Evans notes, "[t]he conditions necessary for a perfectly competitive market would be that, with respect to the sale of any property, there were many buyers, many sellers, full information, and similar properties also on the market". ${ }^{11}$ The fourth element of 'similar properties', in 'perfect markets' traces its origin from the sale of homogeneous goods "usually thought of as some agricultural product like wheat of a specific grade, and the participants in the market [were assumed to] have full information as to the prices of alternative products, etc". ${ }^{12}$ This assumption of homogeneity is not, however, fully applicable to land markets, inter alia, because land is "fixed in location" and "what is apparently being traded" is specific area of land, while "what is actually being traded is some characteristic of that piece of land. ${ }^{13}$

The first and second elements in the definition of the 'perfect market', i.e. the need for 'many buyers' and 'many sellers', are also complex in the context of real estate and land markets. Various categories of sellers of land (or land use rights in the Ethiopian context) have different motives. For example, an owner occupant tends to charge relatively more than what a classical absentee landlord would have sought. For the owner-occupant, the land and the house represent 'home' with various memories and attachments, in addition to the level of indispensability he/she might feel towards continued occupation. Likewise, the developer (as a seller) enters into the market with a different mindset of investment and profit, which varies from that of the classical landlord (who acquires land through inheritance, political pressure or nominal purchase). The developer (as a seller) is also different from a speculator who enters into the real estate market to re-sell at high price in contrast to responsible developers who have a different motive of reasonable profit mark-ups usually commensurate with their value creation. This is because such developers usually have their long-term goodwill and sustainable economic benefits in view.

All these factors can affect land (land use) markets, and in effect render them relatively imperfect. This relative imperfection can, inter alia, be manifested in land price hikes and steady rise in business premise rent which have adverse impact on social wellbeing and the business environment. It is in the context of such imperfections that house markets go through series of house price booms and significant price declines in various cities.

\footnotetext{
${ }^{11}$ Alans W. Evans (2003), Economics, Real Estate and Supply of Land (Blackwell Publishing), p. 7.

12 Id., pp. 48, 49.

${ }^{13}$ Id., p. 49.
} 
While Ricardo focused on factors such as the fertility and inelasticity of rural land in relation to other factors of production, Von Thunen and Alonso's contributions relate to the impact of location and distance (from the market centre) in land markets. Various neoclassical economists have promoted the intervention of planning in the supply side of land to lower land value and enhance access to land. This has led to settings such as intensification of urban land use ${ }^{14}$ (such as higher density construction) ${ }^{15}$ and the extension of urban frontiers to surrounding rural land.

The particular features of real estate property and the imperfection and the relative inefficiency of its pricing have thus brought about different responses. On the one hand, the intervention of the planning option and state intervention is suggested. This emanates from public interest in land and its inherent features which do not warrant the perception of land as a commodity. On the other hand, there is the libertarian view which mainly traces its roots to US thinkers. It is influenced by the setting whereby US homestead farmers mostly owned their own land. Unlike various countries such as Britain, the US homestead farming (and farm owner-occupant) tradition had no symbolic attachment to the ownership of land by the 'Crown'. Nor does the US farmer-occupant homestead farming legacy reflect collectivist influences which prevailed in various traditional societies in Africa and various parts of the world. ${ }^{16}$ This setting has prompted the libertarian view on land markets which, as Evans observes, assumes "that the views of the owners of land coincide with the wants of society so that if agreements are not thought to be necessary by the owners of the land then they are not necessary for the protection of the rest of society". ${ }^{17}$

Even if this libertarian view has its apparent downsides, the other extreme of paternalistic intervention was a failure as was, for example, proven in China's land laws during the 1950s and 1960s which had bestowed land rights on communes. ${ }^{18}$ This extreme had also prevailed in the land laws of the Soviet

${ }^{14}$ Id., p. 31.
${ }^{15}$ Id., p. 38.

16 For example, of the 5,739,657 farms in the United States in $1990,54.9 \%$ of the farms were owned entirely by the occupants, $7.9 \%$ were "owned in part by the occupants and in part by some other person or persons from whom they are rented by the occupants". Another major category of tenure involved tenants on shares (22.2\%) and tenants for cash (13.1\%). See, Henry Gannett (1909), "Farm Tenure in the United States", The Annals of the American Academy of Political and Social Science, Vol. 33, No. 3, Conservation of Natural Resources (May, 1909), p. 164.

${ }^{17}$ Evans, supra note 11, p. 123.

${ }^{18}$ See for example, Yang Yao (2007), "The Chinese Land Tenure System: Practice and Perspectives", [in Ashok Gulati \& Shenggen Fan, Editors (2007), The Dragon \& the Elephant: Agricultural and Rural Reforms in China and India (Johns Hopkins University Press), pp. 49-70]. 
Union and Eastern European former socialist economies. This was mainly attributable to a conception of property rights over land, which goes to the other extreme of undermining and neglecting the market value of land altogether. As briefly indicated in Section 7 below, the economic performance of China, since the mid-1980s shows that a legal regime that classifies land as a domain of public ownership can recognize the ownership rights of landholders over their land use rights (while the state owns the land) and enhance land use markets by allowing urban landholders to participate as sellers (in the form of direct sale or contribution as capital share) in addition to the role of the state as seller of land user rights in the market.

Needless-to-say, land is not the product of human labour with few exceptions which involve human labour inputs (in reclaimed land from coastal waters, marshy land, land fill, etc). Yet, land has attained exchange value owing to its scarcity as population increased and owing to saleable extractions or products from land thereby eventually eroding traditional systems of communal land use and bringing about the gradual emergence and coalescence of individual appropriation. This objective reality renders the subjective denial of market value to land (or land use rights) untenable.

It is to be noted that the imperfection of land markets does not justify the monopoly of land rent through the concentration of land under the control of a few owners. If for example, "a single land owner or landlord owns the whole area, the uses to which the land is put can be restricted, either directly ... or indirectly ... through constraints in the contracts with tenants. If then the amount of land used ... is restricted ... [there will be] higher income or rent from the land". ${ }^{19}$ This evokes a query whether the imperfection of land markets can be rectified if the state regulates the transactions through means such as planning constraints, to which Evans responds: the "observable relationship between the number of properties for sale and ... house prices helps to explain the effects of planning constraints on the amount of land available for development. ... If the amount of land is limited by a constraint imposed by government the implication is that prices will rise. ..." ${ }^{20}$

In other words, such constraints can worsen land market imperfections if they do not significantly increase the amount of land and real estate sellers on the market. In settings which enhance the supply of land to the market through multimodal sources such as the transfer of land rights by private landholders and the enhanced availability of publicly held land through land banks, state intervention to enhance land supply can have positive effects in land markets. Yet, if the land supply mainly comes from the public domain, the state

\footnotetext{
${ }^{19}$ Evans, supra note 11, p. 129.

${ }^{20}$ Id., p. 168.
} 
intervention (through auction) may not lead to low land lease rates as long as many buyers of land use rights chase land rights from a significantly monopolized land bank.

Even if land is an economic asset subject to market transactions, "social, ecological and aesthetic concerns mean that purely market-driven land use will be suboptimal". ${ }^{21}$ These "externality concerns are sufficient in many circumstances to necessitate state ownership of ... environmentally sensitive areas, national parks, roadways, and other public spaces". ${ }^{22}$ It is thus in light of these features of land as an economic asset and other externality concerns that states intervene in and outside the land market by avoiding the two extremes of laissez faire (in the name of free market) and monopolistic or paternalistic land market dominance.

Sustained population growth and urbanization enhance demand and make it difficult to strike a balance between efficiency (productivity) and equity through efficient land markets if land supply is dominated by a single source.

... Unlike other resources or commodities, land is unique in three key respects: (1) It cannot be moved; (2) it cannot, at least in law, be destroyed, (since it is held to be the surface area of a quantity which goes downwards to the Earth's core and upwards into space ...) and; (3) its supply cannot be increased, (in law, land is finite, though in practice usable land can be increased by reclamation programmes). In developing countries, markets in many sectors are often dominated by external factors, making it difficult for them to be self regulating and achieve either productivity or equity objectives. Several factors distort urban land markets and prevent them from being self regulating. Rapid and sustained urban growth has ensured a permanently high level of demand which provides disproportionate benefits to land-owners, or those controlling land allocation. ${ }^{23}$

As Payne observes, stable and steadily rising "level of demand provides guaranteed levels of return on investment" in real property, and as a result "other, more productive sectors of the economy may be unable to match and this serves to attract even higher levels of investment [in real property], which further fuels land price inflation". ${ }^{24}$ This further exacerbates the traditional function of land as "a means of transferring funds generated in the informal, or 'black' economy into the formal sector with minimum risk". ${ }^{25}$ Payne duly notes

${ }^{21}$ Tony Burns and Kate Dalrymple, (2012), in Janelle Plummer, Editor (2012), Diagnosing Corruption in Ethiopia: Perceptions, Realities and the Way Forward for World Bank Group Key Sectors (The World Bank, Washington D.C.), p. 296.

${ }^{22}$ Ibid.

${ }^{23}$ Payne (1996), supra note 1, p. 16.

${ }^{24}$ Ibid.

25 Ibid. 
that "these factors tend to intensify the levels of speculative investment in land and inhibit the efficiency and equity which markets provide in theory"; this is further aggravated by "the considerable distortion which also exists in urban income distribution" thereby making it "difficult to achieve equity in access to land" at affordable prices. ${ }^{26}$

\section{The Paradox between Urban Intensification and Affordability}

Economic activities grow commensurate with the rise in urban population, change in living standards and lifestyles. This brings about the intensification of built up floor space and the frontier expansion of urban centres that are inevitable as long as there is urban population growth. "Most urban economic activities do not require land per se but only the floor space built upon it"; and the "spatial concentration of floor space where economic activities are taking place allows the increasing returns to scale characterizing cities' economies".27 In urban centres, the demand for land is thus "in reality a demand for floor space". ${ }^{28}$ However both reactions to urban population growth, i.e. intensification and urban frontier expansion involve a paradox of bittersweet packages.

\subsection{Intensification}

In urban settings, intensification refers to the intensity in the usage of land for built up area by enhancing floor space of buildings, improving infrastructure and enhancing amenities (parks, open spaces, landscape views, etc) commensurate with the intensification of the built up portion of a city. Bertaud notes that " $[t]$ he consumption of land per unit of floor space varies enormously from city to city and within cities. This variation is due in part to consumer demand and in part to government regulations and government landholdings". ${ }^{29}$

Intensification does not mean haphazardly crowding urban land space with match-box like buildings (irrespective of built up plots vis-à-vis roads cum open space ratio) but rather refers to liveable cities that efficiently use land by enhancing floor space per unit of land. This is the case even in the most densely populated cities because intensification does not mean congestion without due attention to wider streets, street alignments, adequate access to the interior of the city, landscaping, transportation, utilities, noise pollution, glaze and amenities.

\footnotetext{
${ }^{26}$ Ibid.

${ }^{27}$ Alain Bertaud (2010), Land Markets, Government Interventions, and Housing Affordability (Global Economy and Development at Brookings, Working Paper 10, May 2010), p. 6.

${ }^{28}$ Ibid.

${ }^{29}$ Id., p. 18.
} 
A case in point is intensification by upgrading informal settlements and slum areas by significantly enhancing floor space and at the same time equitably accommodating original residents in newly upgraded floor spaces, and concurrently availing significantly augmented floor space for new residential, office space and business consumption. The following figure illustrates intensification in the utility of urban land. It shows the comparative land use between formal and informal settlements in Northern Mumbai, India:

\begin{tabular}{|l|c|c|c|}
\hline \multicolumn{2}{|c|}{} & Informal & Formal \\
\hline Average number of floors & Units & $\mathbf{1}$ & $\mathbf{7}$ \\
\hline $\begin{array}{l}\text { Average floor area per dwelling } \\
\text { (including common corridors and } \\
\text { staircases) }\end{array}$ & $\mathrm{m}^{2}$ & 17.5 & 81.3 \\
\hline Area of floor space per person & $\mathrm{m}^{2}$ & 3.50 & 23.21 \\
\hline Area of land per person & $\mathrm{m}^{2}$ & 4.04 & 6.16 \\
\hline Area of land per m ${ }^{2}$ of floor space & $\mathrm{m}^{2}$ & 1.16 & 0.27 \\
\hline Area of land per dwelling & $\mathrm{m}^{2}$ & 20.22 & 21.55 \\
\hline \% of roads and open space & $\%$ & $13.5 \%$ & $46 \%$ \\
\hline Gross FAR (Floor Area Ratio) & & 0.87 & 3.77 \\
\hline Net residential density & $\begin{array}{c}\text { people per } \\
\text { hectare }\end{array}$ & 2,473 & 1,624 \\
\hline
\end{tabular}

Source: Alain Bertaud (2010)

\subsection{Challenges in the affordability of the substitution of capital for land}

Intensification of urban land-use involves the substitution of capital for land. As land grows scarce, floor spaces in multi-storey buildings substitute the floor space that could have been constructed on land for business and residential purposes. As these floors involve capital, they become attractive to the extent that upward construction becomes comparatively affordable than paying for land space for the construction of a comparable floor space. As Bertaud states, "when land prices are high, land consumption per person will adjust downward, either by consuming less floor space or by substituting capital for land by building multi-storey buildings". ${ }^{30}$ Such substitution of capital for land may also include demolition of old buildings to build new ones normally after "a useful life of around 50 years or more" because "it makes economic sense to demolish that building and build a new one with a rate of substitution closer to the optimum". ${ }^{31}$

There are two sine qua non conditions in the pursuit of consuming less land and using capital to construct floor space upwards. The first relates to the need to observe regulations because the construction should conform to the urban planning requirements and standards thereof. Even if all constructions involve

\footnotetext{
${ }^{30}$ Bertaud, supra note 27, p. 6, footnote omitted.

${ }^{31}$ Id., p. 8.
} 
the observance of these standards, the levels of complexity and rigor of the requirements are directly related with the standard and type of the construction. The second condition refers to "the minimum capital threshold required from households and firms to accomplish this substitution". 32

In areas where land is expensive, developers substitute capital for land by building additional floors on the same parcel of land. Assuming that households and employees consume a constant amount of floor space per person, increasing the number of floors would increase density (both job density and population density), and therefore for a given population it would decrease the demand for land for the entire city. Alternatively, increasing the number of floors would allow increasing floor consumption per person or per job without increasing the demand for land. The floor area ratio (FAR) is the number of units of floor space that are built on a unit of land $[\mathrm{FN}] .{ }^{33}$ It is therefore a measure of the rate of substitution of capital (the cost of construction) for land. ${ }^{34}$

In other words, floor area ratio (FAR) is the total square meters of a building divided by the total square meters of a given plot of land. The higher the FAR, the more dense is the construction. For example, a ground plus one (i.e. twofloor) building with an aggregate floor area of 4,000 square meters is said to have FAR of 1 if it is built on a plot of 4000 square meters with built-up area of 2000 square meters. Each floor area will thus be 2,000 square meters and there will be an open space of 2,000 square meters. If the floors are doubled, the four floors will have an aggregate of $(2,000$ square meters $\mathrm{x} 4=)$ 8,000 square meters on the same plot of land (i.e. 4,000 square meters), and the FAR rises to 2. A similar rise in the FAR occurs if the floors are doubled again to eight floors, in which case the floor area becomes of $(2,000$ square meters x $8=) 16,000$, and the FAR increases to $(16,000 \mathrm{sqm} \div 4,000 \mathrm{sqm}=) 4$.

In the course of intensification, FAR values are accompanied by building footprint regulations so that the external wall to wall area occupied by multi-

32 Ibid.

${ }^{33}$ Endnote 3 of Bertaud, p. 47 reads:

The FAR is the ratio between the total floor space area built on a lot and the area of the lot. FAR values vary, typically from 0.2 in suburban areas to 15.0 in downtown areas. ... The FAR is not equivalent to the number of floors or to the height of buildings. A building footprint rarely covers the entire lot because of the necessity of reserving space for light and ventilation between adjacent lots. For instance, for a building footprint covering 50 percent of a lot, an FAR of 2 would correspond to a four-story building. If the building covers only 25 percent of the lot, the same FAR would allow the construction of an eight-story building. The FAR is equivalent to the number of floor only if the building footprint covers 100 percent of the lot.

${ }^{34}$ Bertaud, supra note 27, p. 6. 
storey buildings leaves a reasonably adequate open area for light and service access. As Bertaud observes, even if the constant building footprint (in a certain urban centre) may be using about 30 percent of the lot while in practice, "higher FAR values usually require lower building footprints to allow more light and services access on the ground. With a 25 percent footprint, the number of floors corresponding to an FAR of 2.4 would be 9.6 stories average for the entire city". 35

Such increase in the enhancement of floor space built on a unit of land operates in the midst of regulatory thresholds and capital limitations. The FAR regulatory thresholds vary between downtown and other parts of the city, and they may not be relevant for suburbs, because the issue of substitution of capital for land may not arise as long as residential and business premise constructions observe urban planning and other modest standards toward construction permit. The FAR regulations in core parts of the city are indeed rigorous thereby constraining the substitution of capital for land as that level of capital cannot be accessed by most entrepreneurs and landholders. Moreover, after a certain level of floors, the capital substitution for land gets into a level of diminishing returns because of the potentially lesser rental demand for higher floors and a possibly enhanced cost of construction per extra floor. Such floor extension further prolongs the timeline for bank loan paybacks due to relatively delayed timeline of completion.

Such crossroads create a paradox between the benefits of intensification and the challenges of affordability. As economic development should be inclusive, this challenge has the potential of pushing many landholders off-track and becomes unthinkable for citizens at middle income and low income levels. "Low-income households do not have always the possibility of substituting capital for land. The cost of constructing a structure that can support several floors is often beyond the means of low-income urban households". ${ }^{36}$ As a result, their recourse is to "consume less land and less floor space". 37

Even if there are efforts on the part of low and medium-level income earners to consume less land and less floor space, it is inevitable that urban redevelopment at some point engulfs these urban areas as well. Intensification can thus have adverse footprints in denying access to small and medium level business activities which in the context of developing countries are very significant in pursuits of inclusive private sector development.

In the course of intensification, land markets facilitate the transfer of land use rights to new landholders. Or, depending on the legal and institutional

\footnotetext{
${ }^{35}$ Bertaud, supra note 27, Endnote 8 p. 47.

${ }^{36}$ Bertaud, supra note 27, p. 8.

${ }^{37}$ Ibid, p. 9.
} 
framework, it might facilitate win-win pursuits which can accommodate benefit shares with former landholders in the form of allowing land use rights as capital contribution and other equitable compensation modalities. Short of such equitable legal regimes, intensification and the dislocation of small and medium income-level citizens will have adverse side effects.

There is consensus that unmediated sales markets do not assist poor and landless households to access land (CIDA, DFID, EU, GTZ, ILC, World Bank). Poor households face numerous obstacles to participating in sales markets, including access to information, and lack of market power and access to credit. These reduce both the equity and efficiency of sales markets. There may be potential for land speculation to develop where land transactions are newly introduced (DGCID). ${ }^{38}$

The other question that arises is whether the small and medium-scale business activities can have enhanced access to rental floor space in newly constructed premises. The challenges in this regard can be volatility of rental rates which can possibly increase at unpredictable pace. This calls for pragmatic and planned intensification in which the state facilitates urban redevelopment through (a) state-managed urban re-development projects, (b) state intervention in the supply of land to the real estate market, and (c) putting in place regulatory and institutional frameworks that enable land use right holders to freely transfer their rights to more efficient users, access bank financing through mortgaging these rights and also contribute same as capital contribution in real estate redevelopment projects which aim at maximizing capital substitution to land.

\section{Urban Land Expansion versus Agricultural Land Conversion (ALC) cum Forest Loss Dilemma}

Land transformation from rural agricultural land to urban land is among the outcomes of urbanization. As observed in the Marakech Declaration ${ }^{39}$ :

The industrial development and the rise of capital during the last century have led to the development of large cities. In developing countries this urban growth is even higher due to higher birth rates. The lack of basic services in rural areas has drawn rural populations to cities, a migration that has a negative effect upon rural and agricultural community, and at the

\footnotetext{
${ }^{38}$ Improving access to land and tenure security, Policy, IFAD, Dec. 2008, p. 31.

39 "The 2nd FIG Regional Conference 'Urban-Rural Interrelationship for Sustainable Environment', held in Marrakech, Morocco, 2-5 December 2003. The aim of the conference was to shed some light on selected issues of urban-rural interrelations and to raise awareness of this complex topic. It also tried to explain the close linkage of land policy and land administration." Marrakech Declaration (Marrakech, Morocco, 2-5 December 2003), Infra note 40, p. 3.
} 
same time deteriorated the urban environment and reduced the quality of life as the infrastructure is insufficient to support such large populations (leading to what can be called "rurbanisation"). ${ }^{40}$

In the context of urban sprawl (i.e. haphazard urban extensions), the frontier expansion of cities involves not only positive outcomes to stakeholders, but also may cause social, economic and environmental tension and disharmony between competing interests. Such urban extensions "absorb productive agricultural land, exploit water resources, pollute the rural environment and [use rural land] as sinks for urban waste". ${ }^{41}$ This reflects the non-efficient expansion of cities and "[t]here often remain extensive rural areas within cities and their metropolitan boundaries, giving rise to the phenomenon of urban villages". ${ }^{42}$ According to the Marrakech Declaration, "a regional settlement structure has to be designed which combines density, mixing of different land uses, polycentrality and capacity of public mass transport systems and public facilities" in order to achieve "the ecological, social and economic targets of sustainability". ${ }^{43}$ This, according to the Declaration calls for priority "to slow down the urban growth" by, inter alia, strengthening "the living conditions and the economic basis in the rural areas" and promoting "new forms of cooperation between cities themselves and between the cities, towns and the villages at the regional level". ${ }^{4}$

Azadi and Hasfiat compare less developed, developing and developed countries in the conversion of agricultural land to urban land and they have examined the drivers thereof. ${ }^{45}$ Their findings show that " $[u]$ rban population was identified as the main driver affecting ALC [Agricultural Land Conversion] in all the countries. Furthermore, although urbanization process exists in all the groups, the developed countries are more successful in managing urban development and ALC". ${ }^{46}$ They note that ALC is the "a logical result of population growth and economic development and it has been neglected as an unavoidable consequence in the development process." However, they suggest that "a stricter implementation of land use and spatial planning or even land conversion laws are needed"; along with "other approaches (such as economic

${ }^{40}$ Marrakech Declaration (Marrakech, Morocco, 2-5 December 2003), "Urban-Rural Relationships for Sustainable Development", FIG Publication No. 33, FIG- International Federation of Surveyors, August 2004, p. 14.

${ }^{41}$ Ibid.

${ }^{42}$ Ibid.

${ }^{43}$ Id., p. 15.

${ }^{44}$ Id., p. 16.

${ }^{45}$ H. Azadi \& Hasfiat (2010), Agricultural Land Conversion Drivers: A Comparison between Less Developed, Developing and Developed Countries, Land Degrad. Develop. (2010), Wiley Online Library (wileyonlinelibrary.com) DOI: 10.1002/ldr.1037

${ }^{46}$ Id., p. 1. 
controls including tax incentives and agricultural subsidies) not only to encourage farmers to remain, but also to improve their farming activities" ${ }^{47}$ China has gone through the challenges inherent in agricultural land conversion and has ultimately set constraints. For example, "the central government imposes a land conversion quota on every major city to preserve agricultural land". ${ }^{48}$

Agricultural land conversion is usually accompanied by the inclination of landholders in the rural areas adjacent to urban centres to sell their agricultural land to attractive offers from developers, speculators or urban dwellers. The prevention of such conversion by direct agricultural zoning can be "a blunt instrument". ${ }^{49}$ On the other hand, removing the right to develop farmland without compensating the owner is difficult to justify. This has fostered 'voluntary' approaches, "including outright land purchase, purchase of development rights (PDR), and transferable development rights (TDR) programs." ${ }^{50}$

The following observation is made regarding agricultural land conversion in China and the pursuits of protection against the steady decline of farmland through land-conversion quotas, market-driven allocation, innovative means of efficient utilization of urban land, and other schemes:

The central government has stated a target of 120 million hectares of farmland to be protected from conversion to ensure long term food security. The concern over the loss of farmland has led to the institution of strict land-conversion quotas, and the farmland protection policy has sought to rein in uncontrolled land conversion, misallocation, and inefficient urban expansion. Urbanization, however, is likely to continue to demand more land into the future, and many localities have devised innovative approaches to reclaim inefficiently used rural land and make it available for urban development. The challenge that remains includes creating a better balance of demand for agricultural land and urban development through improved utilization, transparency, market-driven allocation, and control mechanisms for the appropriate use of land. ${ }^{51}$

${ }^{47}$ Id., p. 8 .

${ }^{48}$ Bertaud, supra note 27, p.11.

49 Ekaterina Gredenko and Dennis Heffley (2014), "Open Space Preservation: Direct Controls and Fiscal Incentives" in the Oxford Handbook of Land Economics, Edited by Joshua M. Duke and Junjie Wu (Oxford University Press), page 518.

${ }^{50}$ Ibid.

${ }^{51}$ World Bank Group (2014), Urban China: Toward Efficient, and Sustainable Urbanization, Chapter 4, "China's Urbanization and Land: A Framework for Reform", (World Bank, Development Research Center of the State Council, the People's Republic of China), p. 268. 
Market-driven allocation, in China, does not mean commoditization of land, but rather a balance between the policy framework which renders urban land public property, and at the same time widening the scope of urban land use rights so that owners of these rights can freely sell the use rights in real estate markets, contribute them as shares in capital mobilization towards high rise building construction, and making use of ownership of land use rights as collateral for bank financing. Efficient utilization of urban land is thus one of the crucial factors in the control against the side effects of haphazard agricultural land conversion. This requires efficient and accurate land information and presupposes effective and transparent land governance.

Urban land-use supply can indeed be significantly enhanced in Ethiopia if land-use holders in urban centres are (pursuant to Article 519 of the Commercial Code) allowed to contribute their landholdings as capital in kind toward the construction of buildings. Such schemes enable developers to invest their capital on construction than lease price loans and compound interest repayment burdens. Even if Ethiopia's land law does not prohibit such capital contributions after the level of construction required by law is done, there is the need for simulation by pretending as if a house (which is going to be demolished) or an unfinished construction (and not land use right) is transferred.

\section{The Need for Land Information and Effective Land Governance}

Access to land presupposes (a) a subject (the person or business) who needs and affords to access land, (b) the object (i.e. the space) intended to be accessed, (c) the modality intended to be pursued, i.e. purchase, rent, etc, and (d) the regulatory and institutional setting which allow, delay or impede the access sought by the subject towards the object in the modality of the subject's needs. The interface between these elements occurs in the context of land administration which involves "the processes of determining, recording, and disseminating information about the tenure, value, and use of land when implementing land management policies".52 These elements of land administration facilitate land management, i.e. "activities associated with the management of land as a resource from both environmental and economic perspectives towards sustainable development". ${ }^{53}$

\footnotetext{
${ }^{52}$ United Nations-Fédération Internationale de Géomètres (UN-FIG) [International Federation of Surveyors], 1999. "The Bathurst Declaration on Land Administration for Sustainable Development." International Workshop on Cadastral Infrastructures for Sustainable Development (Bathurst, New South Wales, Australia, October 18-22), FIG 21, Appendix IV, Glossary of Terms.

${ }^{53}$ Ibid.
} 
Effective and efficient land administration requires a land information system which can be defined as 'a system for acquiring, processing, storing and distributing information about land". 54 This requires a formal registration system which is accurate, current and accessible to the public (including online access).

The need for information services creates the scope for another public good the state can provide: the maintenance of accurate records and information about land rights and obligations. The transfer of land and its use as collateral for credit requires that information concerning the assignment and nature of land rights be available to all interested parties and the public in general. Because functioning land markets are important to ensure efficient allocation of resources, reducing associated transactional costs can have important benefits. In addition, publicly available information can help to better identify and inform decisions about externalities. ${ }^{55}$

Land information includes GIS (Geographic Information System), CIS (Cadastral $^{56}$ Information System), line maps, clearly defined land plot registration, title deed registration which is transparent and readily accessible and other elements of land information and governance. In the current information age which enables the GPS (Global Positioning System) in our mobile phones locate where we are at any given moment, it is indeed expected of land administration institutions to be up to the requirements of our times. As UN-Habitat (2012) notes "[e]nsuring sustainable urban development requires targeted land information". 57

Land information refers not only to the collection and storage of data. It envisages optimal utility by every user of the information in his/her pursuits to access land or to access information regarding the rights of a landholder and encumbrances thereof (i.e., claims against a property by another party as creditor, due to injunction, claims of inheritance, etc). This presupposes governance even though there is "a general tendency to focus too much on data and too little on governance issues" $" 58$ which translate the information into effective access to land. While the land information, inter alia, facilitates "use, access, ownership, taxation, value, transfer and development potential"59 etc.,

\footnotetext{
${ }^{54}$ Ibid.

${ }^{55}$ Burns and Dalrymple, supra note 21, p. 296.

${ }^{56}$ Cadastral map is "a map showing the boundaries of land parcels, often buildings on land, the parcel identifier, sometimes references to boundary corner monumentation. Cadastral maps may also show limited topographic features", Ibid.

57 UN-Habitat (2012), Sustaining Urban Land Information: A framework based on experiences in post-conflict and developing countries, United Nations Human Settlements Programme, Page iv.

${ }^{58}$ Ibid.

${ }^{59}$ Ibid.
} 
the sustainable and effective use of the information toward effective land management needs good governance. These aspects of land information and land governance apply to "land administration (security of tenure and property administration), spatial planning (including regional and urban planning, settlement upgrading and regularization) and environmental management and planning". ${ }^{60}$

Land governance 'refers to the processes by which decisions regarding access to, and use of, land are made, the manner in which those decisions are implemented, and the way conflicting interests in land are resolved or reconciled. Land governance is thus a techno-legal, procedural and political exercise' (UNECA, 2009:40). Good governance means 'that government is well managed, inclusive and results in desirable outcomes. The principles of good governance can be made operational through equity, efficiency, transparency and accountability, sustainability, subsidiarity, civic engagement and security (FAO, 2007:6) ${ }^{61}$

While incompetent and ineffective institutions lead to poor land governance, such settings can be "very convenient for the rich and powerful who benefit from the lack of transparency in urban land management". ${ }^{62}$ Weak or ineffective land governance "include corruption, weak institutions, lack of horizontal and vertical coordination and integration among governmental agencies, limitations on the credit market, and low efficiency of land administration systems" ${ }^{63}$ Such weaknesses in land governance are attributable to a weak 'foundation' for good land governance which "consists of a policy framework, a legal framework, institutional capacity, primary geodetic network, education and training, funding and finance and stakeholder engagement". ${ }^{64}$

\section{Tenure in the Context of Public Ownership of Land}

Article 1205 of Ethiopia's Civil Code has adopted the three elements of ownership (usus, fructus, abusus) embodied in the various civil codes of countries in continental Europe. While a tenant (NhG,e) of a shop has the right to use the premise (usus), one may also agree to transfer both usus (use rights) and fructus (transfer of the rights to enjoy the fruits from a certain property) as in the case of usufruct. The right of abusus (to dipose off) land through sale, inheritance, etc was also embodied in the Civil Code. Even such conceptions of

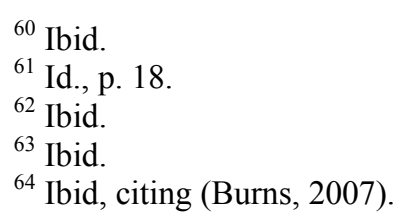


private property over land, however, envisage the public domain and land owned by communities.

On the other hand, various legal regimes do not recognize private ownership of land. For example, all land in English law, in principle, belongs to the Crown while land is privately owned in the US. The security of the landholder in both contexts is not attributable to the tenure, as such, but to the tenure security, i.e. the extent to which the specific tenure (be it in the US or in the English model) is not susceptible to infringement.

In English society ... the reasons go back to the feudal relationships of the Middle Ages. The relationship between the owner and his tenants involved a set of duties on either side, amongst which were the duty of providing armed men, by the tenants, and the duty of defending the tenants, by the lord. In turn, of course, the lords owed similar duties to their feudal lord, the king. Over the years the mediaeval, feudal, relationships were modified, although relics remain. One such is the legal fiction in English law that the monarch is theoretically the owner, in the final analysis, of all land, the actual freeholders holding their land from her (or him). ${ }^{65}$

The same holds true with legal regimes such as Singapore where land is, in principle, publicly owned. However the form of the tenure in Singapore merely determines the scope of the right among tenure categories (leasehold for a maximum period of 99 years and freehold). This classification, however, does not render the landholder with the narrower tenure insecure with regard to the guarantee that $\mathrm{s} /$ he enjoys within the bounds of the bundle of rights included in the tenure.

Property rights in relation to land have been subject of academic and policy discourse for centuries. Locke's 'labour theory of value' relates value with the labour inputs that a person has in a particular object. ${ }^{66}$ The theory of John Locke (1632-1704) was a departure from the notion of 'sovereign will' forwarded by Thomas Hobbes (1588-1679) in which the sovereign "determines the rules that tell every man what goods he may enjoy".

In its Marxist version the labour theory of value is further extended to the notion that 'capital' constitutes the material expression of congealed labour-time which is exploited from the surplus value created by labourers. For Marx, The polarities extend from property rights (including land rights) emanating from the 'sovereign' to the other extreme of abolishing property rights so that every person can, according to Karl Marx (1818-1883) work 'according to his abilities' and enable products of labour to be distributed to 'each according to

\footnotetext{
${ }^{65}$ Evans, supra note 11, p. 116.

${ }^{66}$ See Elias N. Stebek (2011), "Conceptual Foundations of Property Rights”, Mizan Law Review, Vol. 5 No. 1, pp, 10-12.
} 
his needs'. While the Hobbesian conception is statist (i.e. empowering the government to play a paternalistic absolute power in the allocation and withdrawal of land rights), the Marxist conception targets at the abolition of private property in the long run through the short-term phase of socialism.

The FDRE Constitution seems to have been partly influenced by Locke's labour theory of value (Article 40/2), with some Marxist tone manifested in Article 40(3), in spite of its significant departure from the classical Marxist version of landholding which, has been proved to be economically inefficient in USSR's Kolkhozes of the 1930s and Chinese communes of the 1950s. According to Article 40(2) of the FDRE Constitution:

'Private property', for the purpose of this Article, shall mean any tangible or intangible product which has value and is produced by the labour, creativity, enterprise or capital of an individual citizen, associations which enjoy juridical personality under the law, or in appropriate circumstances, by communities specifically empowered by law to own property in common.

This provision (a) states the categories of private property as tangible (which may be moveable or immovable), or intangible such as intellectual property rights, (b) it recognizes the value (i.e. exchange value) of private property, and (c) it articulates its source, i.e., product of labour, creativity, enterprise or capital. Locke's labour theory of value is a general framework rather than a rigid concept, because in the real sense of the term labour usually produces a tangible (corporeal) object by using inputs which the labourer has neither produced nor claimed as an object of his ownership. Nor can a person claim a thing of value merely because he has some inputs in it.

Even if the word 'value' usually refers to the labour inputs in a marketable commodity, there are challenges in the quantification of labour inputs to determine the 'natural' monetary value of exchange of a given product. While the attempts of Ricardo and Marx to address these issues paid attention to the quantification of labour inputs, Adam Smith and other utility theorists rather focused on valuation in terms of 'value in trade' and 'value in use' which are subject to demand and supply during the time of exchange.

The real price of every thing, what every thing really costs to the man who wants to acquire it, is the toil and trouble of acquiring it. What every thing is really worth to the man who has acquired it, and who wants to dispose of it or exchange it for something else, is the toil and trouble which it can save to himself, and which it can impose upon other people. ${ }^{67}$

${ }^{67}$ Adam Smith, An Inquiry into the Nature and Causes of Wealth of Nations (First published in 1776), Book I, Chapter v. 
Apparently, a person is not expected to 'produce' land to own it (but owns the products from land by planting crops and trees ${ }^{68}$ ). In the context of land, its ownership by an individual, a group, community, the state, etc. is not thus attributable to the owner's act of producing it, as such, but is related with factors such as 'use' and 'possession' (usucaption) for a certain period of time ${ }^{69}$ (in the case of original acquisition, other than cases of transfer through sale, inheritance, etc.). Even in legal regimes (such as Ethiopia's Constitution) that do not recognize private property rights on land, the immovable property which is privately owned constitutes an intrinsic element of the land on which it is built. ${ }^{70}$

According to Article 40(2) of the Constitution, a person is owner of the house which is the product of his labour, creativity, enterprise or capital. And pursuant to Articles 1130 to 1132 of the Civil Code, buildings and lands are intrinsic elements. As buildings are materially united with the land on which they are built, the ownership over the building logically extends over ownership over the use right of the land for the period of lease (in leaseholds) and indefinitely for the perpetual permit (grant) system (which in the Ethiopian

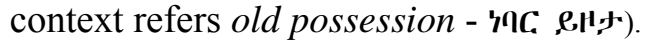

Even if Article 40(3) of the Constitution provides that 'land shall not be subject to sale or to other means of exchange', a person who sells a house for an investor who intends to construct a building, is technically not selling land, but the house that will be demolished by the new buyer. Actually, the 'value in trade' and 'value in use' is the land use right, but the parties in the transaction, and regulatory offices are becoming 'procedurally right' although the core motive of the transaction is the sale of land use right.

Article 40(6) of the Constitution which recognizes the land use rights of investors, and Art 40(7) which guarantees property rights on immovables give due recognition to the 'value in exchange' and 'value in use' of land use rights.

Every Ethiopian shall have the full right to the immovable property he builds and to the permanent improvements he brings about on the land by his labour or capital. This right shall include the right to alienate, to bequeath, and, where the right of use expires, to remove his property, transfer his title, or claim compensation for it. Particulars shall be determined by law.

The tenure and security that the owner of the immovable is entitled to extends to the market value of the immovable which clearly includes the land use value, and the latter terminates only upon the end of the lease term, because at that point the right of the owner, in principle, diminishes to the value of the property

\footnotetext{
${ }^{68}$ See for example, Article 1133 of the 1960 Civil Code of Ethiopia.

${ }^{69}$ See for example, Id., Art 1168.

${ }^{70}$ See, Id., Art 1132.
} 
built on the land. However, even at that stage, equity and efficiency do not warrant the demolition of the property. Thus, the expiry of a land lease period is expected to lead to automatic renewal upon application for renewal, approval by the relevant organ and payment of prevailing benchmark lease price for the land, because the fixed property on the land belongs to the leaseholder.

In spite of these wider interpretations in favour of economic value to land use rights, particular laws (proclamations, regulations and directives) that have been enacted to "determine the particulars" of tenure and security related with land use right have steadily narrowed down the scope of tenure and security of landholders. ${ }^{71}$ With regard to tenure, the misconception that public ownership of land under the Ethiopian Constitution does not cohabit with of the landholder's ownership over land use rights is manifest in the various proclamations, regulations and directives. On the contrary, China, for example (which pursues socialism with some elements of market economy) recognizes private ownership over urban land use rights as highlighted in Section 7. In the realm of security, there is extremely wide definition of 'public interest' embodied in various proclamations, regulations and directive ${ }^{72}$ accompanied by extensive administrative powers in the determination and implementation of expropriation upon meagre level of compensation. ${ }^{73}$ These are manifestations of the denial of economic value to land use rights, and they adversely affect tenure security.

\section{Adverse Effects of Misconceptions in Public Ownership of Land and China's Path toward Reform}

Ethiopia's current land law traces its roots to the 'land to the tiller' movements of the 1960s and 1970s. The notion of public ownership of land was the motto of the political movements that ultimately influenced the rural and urban land proclamations enacted in 1975 which nationalized rural land, urban land and urban extra houses. Many African countries had espoused similar aspirations and resorted to nationalization of land in spite of variation in ideological framework. Land was nationalized and private freehold ownership was extinguished "in 20 out of 40 countries in sub-Saharan Africa just after they became independent from the colonial powers". ${ }^{74}$

${ }^{71}$ See for example Muradu Abdo (2013), "Legislative Protection of Property Rights in Ethiopia: An Overview”, Mizan Law Review 7(2), pp. 180-193.

${ }^{72}$ Ibid.

${ }^{73}$ Ibid.

74 UN-Habitat (2003), Handbook on best practices, security of tenure and access to land (United Nations Human Settlement Programme), p. 14 [Citing Payne, G. (1997), Urban Land Tenure and Property Rights in Developing Countries A Review, IT Publications/ODA, p. 11]. 
Payne states the challenges encountered in "public land-ownership on a large scale, where administrations are weak" and he notes that such nationalization "is not able to guarantee either efficiency or effectiveness in the land market". ${ }^{75}$, Such land-ownership "is particularly susceptible to poor records" and "countries that had extensive private land-ownership prior to nationalization by the former Soviet era countries are better off in terms of records than those who had a small history of private land-ownership" ${ }^{76}$ Under settings of poor records, "occupants must rely for their security of tenure largely on local social land tenure rules and good neighbourliness and hope that their land will not be allocated by the state to someone else. ${ }^{77}$

The nationalization of land in Ethiopia pursued the Soviet and East European model under which urban land was allocated for owner occupants (mainly through self-help residential housing cooperatives or on individual basis) under the perpetual permit system. Post-1991 reforms in most former socialist legal regimes have moved toward private freeholds while China is moving in the path of reform with caution.

The 'Land to the Tiller' movement in Ethiopia culminated in a very radical rural land reform and nationalization in 1975 which had prime focus on 'distributive justice', but which ultimately turned out to be inefficient. Any observer who had the opportunity to periodically visit relatives in rural areas since 1975 can note the demographic and land fragmentation impact of the proclamation in spite its commendable significance in equity and fairness. Higher number of children in a household meant wider land acquisition free of charge upon a young person's entry into hastened marriage thereby acquiring a parcel of land from the plot that was collectively held by the village's Peasant Association. In rural communities where polygamy is allowed more wives meant more landholding for the male dominated family. Subsequently, the parcels from the cooperative farm held by peasant associations were distributed (and at times re-distributed). In effect, the initial hectares per small-holder farmer which had the maximum limit of ten hectares have in the course of inheritance been fragmented to an average of about 0.5 hectares per household in most parts of rural Ethiopia within a period of four decades.

In contrast, South Korea's land reform was pragmatic due to its synthesis of equity and efficiency. ${ }^{78}$ South Korea's nationalization applied only to a small

${ }^{75}$ Ibid, [Citing Payne, G. (1997), Urban Land Tenure and Property Rights in Developing Countries A Review, IT Publications/ODA, p. 12].

${ }^{76}$ Ibid, UN-Habitat (2003).

${ }^{77}$ Ibid.

${ }^{78}$ See Elias N. Stebek (2013), "Overview of Country Experience in Land Rights and Development: South Korea, Taiwan, China and Singapore”, Mizan Law Review, Vol. 7, No. 2, pp. 221-227. 
portion of the landed gentry that was associated with the Japanese invasion, and the land reform mainly implemented a legal regime of compulsory purchase of land beyond certain thresholds upon upfront payment of modest compensation to former landholders by the state, and resale of the land to landless peasants based on nominal prices payable through farm production percentages in a period of ten years. While the Ethiopian option was based on Marxist 'theories', South Korea's path was informed by pragmatic reason which on the one hand addressed the concerns for distributive justice and at the same time considered economic efficiency by enabling former landholders receive modest compensation and thereupon establish non-farm economic activities in rural areas thereby positively contributing to the vibrant economic activities that prevailed in South Korea's rural communities as well.

Ethiopia's agriculture accounts for about $45 \%$ of the country's GNP and for about $90 \%$ of its exports. The challenges of steadily rising population relates not only to rising urban population which is accompanied by urban frontier expansions to agricultural land but it has also led to (a) rural land fragmentation and the frontier extension of farmlands to the detriments of forests, parks and fragile sloppy landscapes, and (b) agricultural intensification through fertilizers and genetically modified seed varieties. The latter can eventually bring about the pesticide treadmill, over-dependence of smallholder farmers on IP owner seed providers and heavy debts payable to fertilizer and seed provision creditors.

The current Ethiopian legal regime has not made a significant departure from the rural and urban land law regimes of 1975 in spite of the policy changes since 1991. Land still belongs to the state, but unlike other legal regimes where land is publicly owned, including China, rural and urban landholders do not have the security and tenure to their holdings commensurate with the level required for effective land management, collateral financing, and transferability to efficient users.

China's legal regime on urban land-use rights has shown significant reform in the realm of tenure transferability despite the public ownership of land. Lessons can be drawn in this regard, not because it represents best practice in terms of tenure security and transferability, but because it indicates that a socialist legal regime (with Chinese characteristics) embodies a wider scope of tenure security and transferability as compared to the Ethiopian legal regime although the two urban land lease regimes seem to be substantially similar. ${ }^{79}$

${ }^{79}$ In both urban land lease regimes landholders are entitled to leasehold for a certain period of years. The scope of the use rights, rights of transfer, the right for automatic renewal of lease period, etc. in China are, however, wider than the urban land lease regime in Ethiopia. See for example the difference between the two regimes regarding automatic renewal in Section 2.1, pp. 53-55 of the article by the same author published in this journal. 
Ethiopian urban land laws fall even far behind China's land reforms, a legal regime which still adheres to the Marxist version of socialism blended with market economy. According to Article 3 of China's 2007 property law ${ }^{80 ~ "[t] h e ~}$ State implements the socialist market economy, ensuring equal legal status and right for development of all market players". Yet, Article 143 of China's 2007 property law provides: "[e]xcept as otherwise provided for by law, the owner of the right to the use of land for construction use shall have the right to transfer, exchange, make as capital contribution, donate or mortgage the right to the use of land for construction use".

Article 143 of China's 2007 property law has two major differences from the Ethiopian legal regime. First, the landholder under China's 2007 property law is "owner of the right to the use of land for construction use". The designation of the right holder as 'owner' of land use right is very significant because it clearly shows a dual-track modality in the ownership of landed property. On the one hand, urban land is owned by the state ${ }^{81}$, and meanwhile land use rights are owned by persons who are lawful landholders. China's property law duly uses the term 'assignment of the right to the use of land for construction use', ${ }^{82}$ and this clearly shows that the use right of the state over the land is assigned to the landholder for the period of the contract thereby rendering the landholder owner of the land use right during the period of contact. Moreover, China's 2007 Property Law ${ }^{83}$ guarantees automatic renewal of lease upon expiry of the period of lease in accordance with the law that embodies the procedures thereof. ${ }^{84}$

Most traditions and civilizations have reverence to land (and nature in general) and refrain from considering it as a commodity. Various social and political systems also have 'legal fictions' of land ownership by a sovereign, as in English law. Ownership of land by the state does not mean that the state as an incorporeal entity actually makes use of and directly controls every square meter of rural and urban land. Public spaces (such as streets, green areas, open spaces), parks, state-owned forests, etc. are directly administered by the state. Such role clearly goes beyond bare ownership because it controls usus (use rights) and fructus (products) so that the assets, resources and amenities can either be accessed by all, or be exclusively used in the manner expressly stated by the relevant laws. In the case of urban land lease, however, the state does not

80 The Property Rights Law of the People's Republic of China, adopted at the 5th Session of the 10th National People's Congress of the People's Republic of China on March 16, 2007, and effective on October 1, 2007.

${ }^{81}$ Id., Art. 47.

${ }^{82}$ See, for example, Id., Art. 138.

${ }^{83}$ Id., Art. 149.

${ }^{84}$ The difference between the two regimes regarding automatic renewal is briefly indicated in Section 2.1, pp. 53-55 of the article by the same author published in this journal. 
own the houses that belong to the landholder (to whom the land use right is assigned) even if the land is under public ownership. This justifies the second track of ownership recognized under Article 143 of China's 2007 Property Law, i.e. private ownership of land use rights during the period of lease.

Secondly, Article 143 entitles the urban landholder in China "to transfer, exchange, make as capital contribution, donate or mortgage" his/her land use rights. Even if urban land is state-owned, the landholder is entitled to any profit accrued in the process of using the land. To this end, Article 135 of China's 2007 Property Law provides that " $[\mathrm{t}]$ he owner of the right to the use of land for construction use shall, according to law, be entitled to possess, utilize and obtain profits from the State-owned land, and have the right, by utilizing such land, to build buildings and their accessory facilities".

Ethiopia (unlike China) does not pledge to pursue a socialist market economy, and the comparison above is meant to merely compare the extent to which China's law provides a stronger tenure for urban leaseholders than Ethiopia's urban land law. Ethiopia rather aspires to pursue the economic policies used (during the 1960s and 1970s) by successful East Asian economies, namely developmental states, with some improvement toward (pursuing the policies of a democratic developmental state). As stated in PSD Hub's Study ${ }^{85}$ (December 2013), these states (Japan, Hong Kong, South Korea and Taiwan) had, during their years of developmental statehood, stronger property rights than other Asian states. The PSD Hub's study also makes reference to Singapore where land is publicly owned in spite of which the law guarantees broad tenure and strong security. ${ }^{86}$

The experience of East Asian developmental states thus prove that the scope of land tenure and its security are crucial in the economic performance of the private sector which constituted the major basis for economic development in these developmental states. Even if these developmental states (unlike the free market minimalist state) actively intervened in the economy, their intervention, as indicated in PSD Hub's study ${ }^{87}$ was meant to empower the private sector by at the same time disciplining its activities through a meritocratic bureaucracy by striking a balance between embeddedness and due autonomy from opportunistic benefits from economic actors. In the context of urban land tenure, the focus of the policy and regulatory framework is thus expected to empower the private sector analogous to the legal regimes of East Asia's developmental states during

${ }^{85}$ Elias N. Stebek, Muradu Abdo \& Hailu Burayu (2013), "Property Rights Protection and Private Sector Development”, PSD Hub Publication No. 23 (Property Rights Development Hub, Ethiopian Chamber of Commerce and Sectoral Associations, Addis Ababa), pp. 91-117.

${ }^{86}$ Id., pp. 112-115.

${ }^{87}$ Id., pp. $98-109$. 
the 1960s and early 1970s, after which these countries have moved onto mature phases of a market economy.

\section{Comparative Experience on Incremental Tenure Titles for Informal Settlements}

The issue of informal settlements raises the concern for access to land in relation to the urban (and peri-urban) poor. Meanwhile, there is the need to control land invasions and squatting. Even though informal settlements are mostly residential, they have relevance in the discourse related with the economic activities of the private sector. The informal land market is one of the sources in land supply, and informal landholdings have influence in the magnitude of access to land to the private sector.

Informal (unauthorized) holdings are different from undocumented holdings that are lawful but have not yet been formally titled (w's: hAר). The latter can occur due to regulatory or administrative constraints even if the holder is entitled to the landholding. Where informal settlement occurs due to necessity (rather undue land speculation), it usually takes the forms of dwelling shades of the needy who have no other choice. Depending on the motive, duration and settings of the settlements, various legal regimes pursue incremental legalization schemes. This, however, presupposes preliminary steps of land information and registration based on surveys of the plots in question according to urban plans. The caveat, in this regard, is the need to observe urban plans and clearly demarcate and protect publicly owned and community owned lands so that legalization of informal settlements does not encourage further unauthorized settlements under expectations of future regularization. As Edesio Fernandes observes based on Brazil's experience:

Policy makers should not forget that the role and obligation of the state, as recognized in international documents and national laws, is to provide adequate social housing. This is by no means the same as recognizing ownership titles, let alone individual titles; in fact, especially as regards settlements on public land, individual ownership [in informal settlements] may not always be the best option. Moreover, given the scale of the phenomenon of informal land development, there is no way it can be tackled only through the attribution of individual ownership titles, and collective legal solutions need to be considered. ${ }^{88}$

Payne calls for caution before individual ownership titles are regarded as appropriate options in the context of informal settlements.

${ }^{88}$ Available at $<\mathrm{http}: / /$ www.dpuassociates.net/system/files/Urban+Land+Regularization+Prog+in+GlobalPoverty.pdf>, Accessed, 25 January 2015. 
Whilst the granting of full title may be of considerable benefit to local landowners, investors and settlers, it may also lead to dramatic increases in rent levels which may force existing tenants out of the area. Secondly, sudden increases in land or property values may encourage some settlers to realise the enhanced value of their property and sell out to higher income groups, thereby reducing the social coherence of settlements and making it more difficult for other low income households to gain access. El-Batran (1994) cites the case of Ismailia, where the introduction of full titles and development standards led to an increase in rent levels for three room units from $£ 2$ to $£ 24-30$, in addition to $£ 1,000$ key money in local currency. ${ }^{89}$

Payne notes the heavy indirect price that can ensue due to the provision of full tenure to informal settlements because "benefits granted to existing unauthorised settlements may well encourage the formation of others". ${ }^{90} \mathrm{He}$ underlines the need for the provision of housing for the urban poor in informal settlements, but suggests that incremental options such as rental tenures can be relatively better options than individual freeholds, because the latter (in the context of informal settlements) can bring about "adverse short and medium term impacts on the efficiency and equity of urban land markets". ${ }^{91}$ According to Payne, these adverse effects may include (a) "the ability to make substantial profits merely from holding and transferring land, without investing in its improvement or paying taxes on its increasing market value", (b) the short-term attraction of "even greater levels of investment", and (c) ultimate adverse effect because this "in turn reinforces land price inflation and diverts funds which could be put to more productive economic use". Payne thus argues that "[i]n this sense, free, or unconstrained, urban land markets may serve to inhibit, as well as facilitate, national economic development". ${ }^{92}$

Thailand illustrates the merits of an evolutionary approach to its system of tenure and property rights in accordance with changes in demand. Botswana is another good example of an incremental approach to tenure reform; the Presidential Commission on Land Tenure of 1983 concluded that "in the final analysis... it became clear that the desires of people are not for new and radical forms of land tenure but rather for easy access to land". It also recognised that "new needs exist, but old needs persist" and concluded that "the land tenure policy which has been pursued by Government may be described as one of careful change, responding to particular needs with specific tenure innovations. ${ }^{93}$

\footnotetext{
${ }^{89}$ Payne, supra note 1, p. 51.

${ }^{90}$ Ibid.

${ }^{91}$ Ibid.

92 Ibid.

${ }^{93}$ Id., p. 52.
} 
Tenure innovations in the context of informal settlements include "[i]ncremental and pragmatic regularization schemes" such as "group tenure arrangements" which can take the form of "housing associations involving large amounts of land and housing stock under one agency" so that the "agency would take responsibility for the land administration involved". ${ }^{94}$

Given that there is a vast number of people living under group forms of tenure, both family and wider group, and that the individualization of titles/deeds often breaks down the social cohesion of the group, group forms of tenure are taking on more importance in many parts of the world (Payne:1997). UNHABITAT recommends that community, collective, or cooperative land-ownership is adopted as it can provide a permanent or intermediate form of secure tenure. "Within such community-controlled and managed land, a range of tenure arrangements suitable to community needs can be accommodated including rental, short and long-term tenure." (UNCHS:1996b:8). ${ }^{95}$

Tenures such as "local leases and group tenure approaches, as well as other forms of recording these approaches" are believed to be pragmatic and relatively favourable to the urban poor. ${ }^{96}$ This approach considers regularization as an ongoing incremental process "as individual connections to services, housing consolidation and the upgrading of tenure to individual rights take place". The process also involves "the gradual servicing of informal settlements in the city and in expanding peri-urban areas. In addition, this form of regularization relies on community involvement for the sake of sustainability during both the development and the ongoing maintenance of services and land records" thereby altering "conventional approaches to city governance". ${ }^{97}$

Matthaei and Mandimika relate these views on incremental tenure systems with developments in Namibia. They support the incremental "process of moving along the continuum from complete illegality to formal tenure and full property rights" thereby reducing "the potential risk of undesirable social consequences" by gradually increasing the residents of informal settlement "rather than moving directly from informal to private tenure rights". ${ }^{98}$

${ }^{94}$ UN-Habitat (2003), supra note 74, pp. 23-24.

${ }^{95}$ Id., p. 24 [citing Payne, G. 1997 Urban Land Tenure and Property Rights in Developing Countries A Review, IT Publications/ODA; and United Nations Centre for Human Settlement (Habitat) (1996b) New Delhi Declaration, Global conference on access to land and security of tenure as a condition for sustainable shelter and urban development. New Delhi, 17th -19th January, 1996. Preparation document for Habitat II, Istanbul.]

${ }^{96}$ Id., p. 28.

${ }^{97}$ Id., p. 87.

${ }^{98}$ Elke Matthaei \& Prisca Mandimika (2014), The Flexible Land Tenure System in Namibia: Integrating Urban Land Rights into the National Land Reform Programme 
This is already done in some countries; whereby good examples are the 'Certificates of Use' in Botswana and Lesotho, condominium rights in Brazil or extending existing customary arrangements in Egypt. In the case of Egypt, informal settlers are charged a modest ground rent. This rent does not grant a title and the land cannot be transferred, however should households be displaced, they will receive compensation for the buildings they have erected on their land parcels (ibid). This ... enables the poor to access land parcels which would normally have been beyond their financial means. ${ }^{99}$

Botswana's innovative tenure option known as 'Certificates of Rights (CORs)' was introduced in the early 1970s in response to rapid urbanization and the subsequent increase in informal settlements of the urban poor. ${ }^{100}$ They were options which avoided the complex and costly procedures of registration and formal titles aiming at facilitating self-help housing which could incrementally be upgraded to formal title deeds. ${ }^{101}$ In spite of various challenges including the transfer of plots to real estate developers and land speculators, the benefits indeed outweigh the challenges encountered.

In Namibia, the Flexible Land Tenure Act, Act No. 4 of 2012 was enacted "(a) to create alternative forms of land title that are simpler and cheaper to administer than existing forms of land title; (b) to provide security of title for persons who live in informal settlements or who are provided with low income housing; [and] (c) to empower the persons concerned economically by means of these rights". ${ }^{12}$ This Act was a response to the challenges of "over 235 informal settlements and 134,884 families" that were affected in Namibia". ${ }^{103}$ The Flexible Land Tenure System (FLTS) introduced tiers of titles that are incremental and which may ultimately lead to freehold titles. The first phase is known as the Starter Title which can incrementally lead to the second phase, Land Hold title.

(Paper prepared for presentation at the "2014 World Bank Conference on Land and Poverty”, The World Bank - Washington DC, March 24-27, 2014), p. 12 [citing Payne, G. 2001. Urban Land Tenure Policy Options: Titles or Rights? Habitat International (25):427].

${ }^{99}$ Id., pp. 12, 13.

100 See, Boipuso Nkwae \& Dixon Dumba "From Certificate of Rights to Long-Term Leaseholds in Botswana", University of Botswana, Gaborone, Botswana. $<\mathrm{http}: / /$ www.researchgate.net/publication/223839821_From_certificate_of_rights_to_longterm_leaseholds_in_Botswana>

${ }^{101}$ Ibid.

${ }^{102}$ Flexible Land Tenure Act No. 4 of 2012, Government Gazette of the Republic of Namibia, No. 4963, Windhoek, 13 June 2012, Section 2.

${ }^{103}$ Matthaei \& Mandimika, supra note 98, p. 20. 
These two titles are individual types of tenure, however they are group based. The rationale being that the outside boundary of a block of land that is earmarked for titling under the FLTS is professionally surveyed and registered under the freehold tenure system in the Deeds Registry in Windhoek, while individual rights or plots within the block are registered locally in the established Land Rights Offices (LRO). The ownership of the block piece of land (Erf) can be with the Municipality, private developer or a Community Based Organisation (CBO). The maximum number of households per starter title or land hold title is not limited to 100; however there have been suggestions to limit a block to 100 households to avoid overcrowding (Hackenbroch \& Konzonguizi, 2005). ${ }^{104}$

The holder of a starter title has the following rights:

a) to erect a dwelling on the blockerf ${ }^{105}$ at the specified location of the specified size and nature;

b) to occupy the dwelling referred to in paragraph (a) in perpetuity;

c) on his or her death to bequeath the dwelling to his or her heirs and to lease to another person;

d) subject to subsection (3), to utilise such services as may be provided to the scheme as a whole by a local authority or any other person;

e) to transfer his or her rights to any other person, (whether that person is the heir of the holder of that rights or whether the transfer is another transaction recognised by law);

f) to be a member of the association of the scheme concerned. ${ }^{106}$

Starter title can be "transferred by agreement followed by occupation of the dwelling concerned by the person to whom the right has been transferred or any person assigned by him or her to occupy that dwelling" ${ }^{107}$ However, it must be noted that "[n]o natural person may hold more than one starter title right and no person may acquire a starter title right if he or she is the owner of any immovable property or a land hold title right in Namibia". ${ }^{108}$ This restriction is attributable to the transitional nature of the tenure which is meant to address the shelter needs of the urban poor who live in informal settlements and eventually be upgraded to stronger tenure schemes.

\footnotetext{
${ }^{104}$ Id., p. 21.

105 "blockerf" means a piece of land on which a starter title scheme or a land hold title scheme is established" (Section 1, Flexible Land Tenure Act No. 4 of 2012, supra note 96).

${ }^{106}$ Section 9(1), Flexible Land Tenure Act No. 4 of 2012, supra note 102.

${ }^{107}$ Id., Section 9(4).

${ }^{108}$ Id., Section 9(10).
} 
The land hold title "is a statutory form of tenure with all of the most important aspects of freehold ownership, however without the complications of full ownership". ${ }^{109}$ It provides the owner with rights that are "[s]imilar to freehold in a designated plot [t]o occupy a defined site in perpetuity"; the land hold title can "be transferred, is devisable [i..e, transferable by will] and can be used as collateral". ${ }^{110}$

These rights are recorded in the land hold title register established by the Registrar of Deeds and located at a LRO by a land rights registrar. The site of a land hold title is demarcated on a cadastral map which is held in the LRO. In this instance, the holder can enter into a limited range of commercial activities. Once tenure security is obtained, the holders of these titles can build their own houses and the local authority will be expected to provide other services. Land under land hold title may be sold, donated, inherited and mortgaged, and as such be sold in execution. ${ }^{111}$

The starter title can be upgraded "to the land hold title or directly to freehold title" but "upgrading of starter title rights is only possible if the whole group, or at least $75 \%$ of the group occupying a block of land, decides to upgrade". ${ }^{112}$ Registration is then made after layout planning is "finalised and approved so that individual plots can be defined and allocated". ${ }^{113}$ However, "the land hold title can be upgraded to freehold title either individually or as a block of plots". ${ }^{114}$ And finally, the free hold title constitutes "the final step towards full cadastral title, and includes procedures of surveying and results in the proclamation of the whole block development as a new extension of the town". ${ }^{115}$

Addressing the problems of informal settlements require caution against two extremes. On the one hand, even if informal settlements are unlawful, rigid legal procedures of eviction and other measures are usually imprudent and unjust. On the other hand, blanket regularization and the automatic issuance of individualized title deeds are susceptible to the risk of encouraging future informal settlements on public land, and some may even sell their holdings to land speculators and move to other informal settlements. The good practices of various countries can thus inform the need for incremental means of legalizing landholding in informal settlements through flexible schemes which in the shortterm do not immediately lead to individualized title deeds to the landholding.

\footnotetext{
${ }^{109}$ Matthaei \& Mandimika, supra note 98, p. 22.

${ }^{110}$ Ibid.

111 Ibid.

112 Ibid.

113 Ibid.

114 Ibid.

${ }^{115}$ Id., p. 23.
} 


\section{Conclusion: The Way Forward Beyond 'Isomorphic Mimicry'}

Production and exchange have always been private engagements. As economic activities became so complex and multifaceted, state intervention was necessary to regulate and institutionalize the basic rules and processes of these activities. The conventional minimal (thin) state confined its role to its police, defence, taxation and adjudication functions until post-industrial economic activities required enhanced regulatory schemes. During the last two centuries, intervention in the provision of public goods has become inevitable. However, extremist forms of command economy that substituted the private sector, or that substantially sidelined the private sector toward peripheral roles in economic activities have invariably failed in post-1949 China until the early 1980s, in the former Soviet Union and East European countries. This proves that it takes millions of hands, minds and hearts of a country's adult population to produce the goods and services that are needed for the livelihood, social wellbeing and progress of the entire population.

The value chain of every product thus renders empowerment at all levels crucial because productivity, competitiveness and economic development are unimaginable without access to land at all tiers of the chain. It is to be noted that access to land in its broader meaning is different from access to the highest bidder. It rather means the accessibility of land based on effective and efficient regulatory and institutional frameworks which balance equity and productivity. This envisages broad-based access to land and empowerment which motivate productivity beyond consumption thereby serving as a springboard toward saving, the mobilization of resources, enhanced investment and sustainable development. Grassroots empowerment thus requires land tenure and security that constitute indispensable inputs in the economic pursuits of citizens.

Business activities operate with ease in settings which, inter alia, have access to land with a significant level of tenure security accompanied by the availability of urban land at affordable prices. This envisages multi-track landrelated markets that are not overwhelmed by imperfections. Market distortions can bring about land-use price hikes thereby diverting capital to land speculation and real estate bubbles to the detriment of other economic activities such as modern agriculture and manufacturing which are the foundations for valueadding economic pursuits.

This brings about knock-on effects of rental hikes (unmatched by a proportionally increasing real income) which eat away the major part of salaries and wages of the urban population thereby adversely affecting motivation, productivity and social wellbeing. In the case of the self-employed, such rental hike and shortages of residential and business rental premises render productivity and saving difficult. This inevitably brings about focus on settling daily household bills rather than saving, entrepreneurship, innovation and 
investment. Nor can price caps on house rent solve the problem because such measures would aggravate market imperfections by encouraging underground rental deals, and can also push rental contracts toward the incorporation of invisible elements such as ties and relationships. The way forward thus requires enhancing access to land (with tenure security) through non-monopolized multitrack land-use markets that positively contribute toward ease in doing business.

Ethiopia's urban land law (which pledges to pursue robust free market economy as stated in the Lease Proclamation) in fact embodies land use rights that are narrower and weaker than the tenure security in China's property law, which pursues socialist market economy. Nor are the restrictions justified under the land property regimes of East Asian countries that (during the 1960s and early 1970s) pursued state interventionist policies of developmental statehood. It is to be noted that these developmental states had in fact empowered, and not substituted private economic actors. The way forward thus calls for drawing lessons from the legal regimes of developmental states with regard to access to land and tenure security. Another major good practice that can inform the way forward in the path of incremental tenure schemes is Namibia's legal regime on the incremental regularization of informal settlements.

The way forward in Ethiopia thus envisages the significant enhancement of the supply side of urban land-use rights through diversified tracks of real property supply, inter alia, by setting aside the current restrictions in the transferability of land use rights. Such setting calls for (a) the enhancement of the transferability of real property for the more efficient user at market value with due regulatory interventions against land speculation and holdouts (i.e. landholder's undue demand for exaggerated prices beyond market value during urban redevelopment) and (b) share transfers by way of enabling land-use right owners to contribute the market value of their land-use rights as stock (share) contribution in investment projects including construction of buildings.

Piece-meal reactive measures in the form of over-regulation merely delay solutions thereby causing opportunity loss and the entrenchment of the problems and challenges. As Pritchett and de Weijer duly observed, there is the need to avoid 'isomorphic mimicry' because it is real (de facto) performance rather than mimicry of structures and directives ${ }^{116}$ that can holistically resolve challenges and problems. They further call for the need to distinguish between "optimism, which can be a powerful positive force, and wishful thinking, which is not". ${ }^{117}$ Moreover, they underline the need to avoid "pre-mature load bearing" by

${ }^{116}$ Lant Pritchett \& Frauke de Weijer (2010), Fragile States: Stuck in a Capability Trap (World Development Report, Background Paper), Harvard Kennedy School October 29, 2010 , p. 2.

${ }^{117}$ Ibid. 
"asking too much of too little too soon too often". ${ }^{118}$ Entrusting municipal and land management offices to address every problem and challenge that emerges in the realm of land supply and transferability can thus lead to 'isomorphic mimicry' rather than healthy land markets and effective land governance. Even worse, such state-centric monopoly toward mono-route land-use markets diverts municipal offices from their mainstream function, thereby creating gaps in the municipal provision of utilities, waste management, transport management, urban plan management, land governance and other municipal services.

As the property regime is one of the key elements among formal and informal institutions, it involves sets of restraints and claims in economic, social and political interactions. These elements of institutions involve "the understanding of how rules are embedded in social life and how institutional structures are sustained". ${ }^{119}$ World Bank Report indicates that "the proportion of real property is between one-half and three-quarters of wealth in most economies". ${ }^{120}$ This clearly shows the indispensability of effective land law regimes that are conducive to the enhancement of social wellbeing and economic performance. Procrastinations and failures to address problems and challenges in these legal regimes can ultimately lead to varying degrees of systemic corruption and polarized economic benefits in the midst of mass impoverishment and institutional fragility.

Every success in the transposition of a challenge (or a problem) onto a solution positively contributes to the enhancement of a country's institutional capabilities, which determine the dynamics in the pursuits of economic, social and political progress. On the contrary, regression can lead to fragility. Once a state regresses into fragility, there is the tendency to remain fragile. ${ }^{121}$ This is because such states usually get 'stuck' in the midst of "combination of unfavorable domestic conditions plus unhelpful external actors" thereby suffering from low capability and "recurrent conflict, for a very long time". ${ }^{22}$ That is precisely why prudence calls for proactive pursuits of prevention (rather than post-facto curative efforts) against all risks of fragility, toward which issues such as access to land are crucial.

\footnotetext{
118 Ibid.

${ }^{119}$ Geoffrey M. Hodgson (2006), "What are Institutions”, Journal of Economic Issues, Volume XL, No. 1, March 2006, p. 18.

${ }^{120}$ Cited in Kenneth W. Dam (2006), Land, Law and Economic Development (January 2006), Chicago Working Papers in Law and Economics (Second Series)

${ }^{121}$ Pritchett \& de Weijer, supra note 116.

122 Ibid.
} 